\title{
RETHINKING THE NEW INTERNATIONAL DIVISION OF LABOUR THROUGH THE LENS OF GENDER AND CLASS DIFFERENCES: GARMENT INDUSTRY AND PRISON LABOUR
}

\begin{abstract}
This paper pays attention to the socio-economic aspect of the so-called "new international division of labour" or "global value chains" from a gender perspective. It analyses the garment industry and the prison labour known as "prison industrial complex" as part of the structuring and the division of labour on a global scale. Drawing from theories and research on global development, neo-marxist feminist theory, as well as the current events taking place in the economy and labour market, this work argues that the "new" international division of labour is unsustainable and harmful for women around the world in particular and for all socially vulnerable categories of people in general. At the same time, this paper presents the necessity for a gender sensitive policy-making that takes into account the specific context which both women and men are situated in, as well as the specific gendered effects emerging from the socio-economic politics of global development.
\end{abstract}

Keywords: NEW INTERNATIONAL DIVISION OF LABOUR, GARMENTS INDUSTRY, PRISON LABOUR, GENDER, CLASS DIFFERENCES, NEOLIBERALISM, NEO-MARXIST FEMINIST THEORY

\section{Introduction}

The late ' 60 s and early ' 70 s of the $20^{\text {th }}$ century saw a new form of division of labour on a world scale so-called "New International Division of Labour" [new IDL] (Mies, 2014; Fröbel et al., 1978; Gamburd, 1998; Komlosy, 2018; Snow, 1983; Nash, 1983; Benería, 1989; Lim, 1983; Ong, 1983). The main idea encompassed by this concept is the shift of manufacturing on a global level - from importing raw material from developing countries (of the Global South) into the developed countries (of the Global North) to exporting the whole production process in the developing countries.

Although fluctuating over time, there is still evidence of an ongoing vertical division of labour globally. This means that (usually) Western multinational corporations in the search for cheap labour force, flexible working arrangements and easy trade conditions have been moving their production sites to the countries in the Global South, while different sectoral industries in the developed countries of the Global North have almost disappeared. 
This shift of production sites and manufacturing has had not only economic impacts but also social ones, such as controversial working conditions and policies, gender inequality and human rights' violations (Armbruster-Sandoval, 2005; José Alonso, 1983).

This shift sets the questions about the sustainability of the system of 'new' IDL and binary positioning of the countries in the Global South as the main producers of goods vs. the countries of the Global North as the main consumers of these goods (Komlosy, 2018; Staritz et al., 2016). This paper analyses the social aspect of the international division of labour, questioning its sustainability in today's economic and socio-political context from a gender perspective and class differences. It focuses on the garment industry and the prison labour known as "prison industrial complex" (Davis, 2003).

\section{New International Division of Labour from a Gender Perspective}

Engendering from the global restructuring of the way of production and the shift of production sites from the Global North to the Global South, the new international division of labour tangles the gender - or as some authors call it, the sexual - division of labour (Mies, 2014; Enloe, 1983).

The policies that have promoted and sustained the new international division of labour such as the establishment of free trade zones and flexible working arrangements have resulted in profit accumulation for the multinational corporations and the exporting state economies in the Global South. The original idea of this neoliberal structure was economic upgrade of the countries in the global South by lowering the unemployment rates, which eventually should have led to lowering the level of poverty in these countries. However, the scholarship in the field of global development shows that the economic and the social upgrade of a country are not always positively correlated. On the contrary, the econometric analysis in the Global South have proven that whilst economic upgrade has been noted in these countries the majority of the local population has not felt the improvement. Furthermore, despite the economic progress the index of human rights and gender equality has been stagnating (Bernhardt and Pollak, 2015; Milberg and Winkler, 2013; Bernhardt and Milberg, 2011; Barrientos et al., 2011). Contrary to what was expected, the politics of neoliberalism have encouraged cruel competition both on the trade and on the labour market globally which affected women and their labour disproportionately worse than men (Bhattacharya, 2013). Women became the optimal labour force in the most low-paid and insecure industries in the Global South, while they were also the first to lose their jobs with the closure of the production sites in the Global North.

Feminist scholars named this process housewifization (Mies, 2014; Fraser, 2016; Petkovska, 2016; Komlosy, 2018). It points to the tendency to divi- 
de the economy on formal, or the so-called modern, visible sector mainly employed by men, and informal, invisible sector represented majorly by women workers. Yet, women working in this sector are often not even considered as workers but as housewives (Mies, 2014). In other words, housewifization is externalization of the labour that would otherwise be paid. It does not only mean feminization of the labour, or devaluing and paying less for the job positions traditionally represented by women, but it also means not recognizing women as workers. As Maria Mies points out "women's labour is considered a natural resource, freely available like air and water" (Mies, 2014: 110). According to her, housewifization is a strategy of the international economy to incorporate women in the processes of capital accumulation. Despite the understanding of women as housewives, they still are the optimal labour force on a global scale (Mies, 2014). Considering women's work as auxiliary instead of crucial and therefore unworthy of equal pay, the profitability of this work is the highest.

The process of housewifization mirrors the depreciation of women's labour especially that of working class women. The loss of women's jobs because of factories' closure in the Global North it is not considered a big damage as it only affects the auxiliary, invisible labour of women. This loss is considered non-damaging for the families of these women nor for the state economy. On the other hand, what is produced in the Global South needs to be consumed. In that sense, housewifization is a way to represent women in the Global North as consumers of the imported goods. Hence the development of the feminist critique on consumerism in the developed countries arises. Drawing on Herbert Marcuse's One-dimensional Man, Nina Power in her book One-dimensional Woman (2009) criticizes the consumerist ideology of the capitalist society in respect to women and their representation as emancipated consumerists. By analysing the media discourse in the developed countries, Nina Power and Maria Mies show how the advertisement of a wide range of products is targeted towards the female consumer (Power, 2009; Mies, 2014). In that way, women's emancipation is promoted through consumerism.

However, it does not mean that the new ideological and structural division of labour has been promoting displacement of women from the labour market in the private sphere of unpaid labour. Women are still expected to work but for smaller wages and in insecure job positions. As Lise Vogel argues, women and other socially vulnerable groups of people represent the army of reserve labour force (Vogel, 2013). They are always available to the labour market, but due to their inconstant presence on it and the traditional notions of what constitutes a woman's role intertwined with the historical practice on the matter, they are usually found on the bottom of the labour relations ladder. 
Hence, the new international division of labour significantly worsened the conditions on the labour market both for the women in the Global South and for the women in the Global North. Besides dividing women's position geographically, the new IDL has also divided them in terms of class as producers vs. consumers (Mies, 2014). However, the largest portion of the theory on the new international division of labour does not take into account the specific conditions of all women and therefore can hardly predict how a possible crisis of the new international division of labour will affect women on a global scale.

\section{Garment Industry and Gender}

The Garment industry is one of the largest industrial branches that is directly affected by the new international division of labour. It is considered to be "the most globalized industry" as well as the first industrial branch affected by the international shift of the division of labour (Armbruster-Sandoval, 2005: 3).It is also occupied majorly by women workers on a global level partly due to traditional understandings of the gendered division of roles and professions. Working with textile and production of clothes has been historically related to the placement of the woman in the private sphere and to the patriarchal notion on her role as a housewife and a caregiver (Mies, 2014; Federici, 2004; Fraser, 2016).

However, this is not the only industry depending directly on women's labour. More recently, the electronics industry, i.e. the manual assembling of electrical parts for mobile phones, computers, etc. has employed similar approach. Due to the difficulty to automatize such processes of assembling small electrical parts, women's hands were found to be the most suitable ones for this type of work. Thus, women are the optimal labour force in such industries due to the labour intensive, low paid and insecure job market, or in other words due to the feminization of labour.

Considering from any point of view, women are disadvantaged in comparison to men when it comes to the position on the labour market on a global level. Considering the garment industry more specifically, precisely due to the feminization of this industry, it is much easier to manipulate with it as opposed to with those industrial branches that are more stable, better paid and reserved primarily for men. For instance, the garment industry is an easy one to dislocate depending on the needs of the world economy and different political agendas.

Studies that are more recent show growing economies and rise of the consumption power of the population in the countries in the Global South (such as Bangladesh, Vietnam, Cambodia, China etc.) that are major sites for production of garments for the European market. These countries are no longer happy "with their position at the low end of the chain" (Komlosy, 2018: 
216). They are forming alliances and are making strong efforts to becoming major players in the global commodity chains. Andrea Komlosy in her latest work on the historical turn of work as an ideological concept opens the question of a new possible shift in the economic and socio-political power between the countries on a global scale (Komlosy, 2018). Therefore, we must ask, what would happen if the European and the American market were no longer capable of importing, inter alia, cheap garments from the countries in the Global South? One of the alternatives suggested here is in such case there would be a new displacement of certain industrial branches to sites where labour is even more exploitative and cheaper. Such locations are prisons and countries on the semi-peripheries of the Global North, for example Eastern and Southeast Europe. With the transformation of the political and the economic systems, these regions have lost the heavy industry but not the "feminized" ones such as the garment industry (Ѓуровска, 2008). This industry, in our country included, mainly hires women, who work over the hour in horrible inhumane conditions, for minimal wage and often times even for less in order to export (primarily military) garments to the German market. While working in this branch, whole cities in North Macedonia depend directly on the labour of women. Women are the optimal labour force in this industry and at the same time bear the double burden of caregivers and breadwinners for the home (Petkovska, 2016). Despite being the major breadwinners, the housewifization once again contributes to the devaluation of these women's labour.

The exploitation of women's labour is not applicable in the same mode and degree everywhere. Different conditions for exploitation have emerged during the socio-economic development of different countries. This characteristic of the neoliberal system as a new form of capitalism makes it easily adjustable to any situation. Therefore, whilst some ostensibly free women in the semi-peripheries of the Global North work in factories for production of garments, other working-class women and racially undesired groups of people work in prisons in the Global North for the same purposes. This is the latest trend of adjusting neoliberalism to the new economic conditions in order to accumulate capital through the integration of the reserve army of labour.

\section{Prison Labour}

In the beginning of the 1990s, the theoreticians of the so-called black feminism and the activists against racism in the USA detected and criticized the concept known as "prison industrial complex" (Davis, 2003; DuVernay, 2016). In this period, prison population started growing through utilization of racial profiling of socially vulnerable people of Afro-American or Latin 
origins; prisons were turned into industrial complexes for manufacture of goods.

In her book Are Prisons Obsolete? (2003), professor and activist Angela Davis highlights the reforms in the Californian prison system in the early '90s as the germ of the prison industrial complex. It was then when prison labour was utilized for the first time for agricultural purposes. Soon after, this type of production has become the major competition branch to the agro-business in the USA. Davis stresses that contrary to the logic, at the time of lowering of the crime rates in the country the number of prison population has been rising with socially vulnerable people being the predominant part of this population (Davis, 2003). Although these people have not committed significantly higher criminal offences in comparison to privileged groups of people they served longer sentences. All this was in order to create the reserve army of labour. Hence, the prison industrial complex has become another link in the neoliberal chain for profit accumulation.

Nowadays many American corporations depend on prison labour almost in every industrial branch - from wine plantations work to production of garments and furniture. This is not only the American case but also the case in „Europe, South America and Australia” (Davis, 2003, 85). Recently, through the new prison reforms Italy has started implementing the model of prison labour exploitation (Squires, 2013). These circumstances open the possibility for a structural change in the international division of labour: Cheap labour power now belonging to the Global South to shift back to the industrial cradles and in the hands of the working class people who are working from inside the prisons.

Racial profiling and discrimination against socially vulnerable people are more likely to be performed and accepted in countries predominated by white race and financially well situated population. In these countries, people from lower classes are thought of as operating labour supplies. At the same time, the ground for social unrest due to this setting is quite unfavourable as such human rights violations do not concern the majority of the population. Furthermore, as Michel Foucault points out, the structure of today's prisons is set to the discourse of delivering the sentence behind closed doors far from the eyes of the majority of population that could question the functioning of the prison system (Foucault, 1975). Protected from critique, the prison system is an exceptional opportunity to become the new platform for labour exploitation.

\section{Conclusion}

The new international division of labour, the garment industry and the prison system looked through the lens of gender equality and human rights are in the basis of the feminist critique of neoliberalism. As previously 
pointed, the scholarship within the field of global development studies is mainly directed towards econometric results, which gives clear picture of the general relations between countries on a global level. However, whilst some of this research has detected the gender dimension of these relations, it misses to acknowledge its crucial role in the division of labour and the shift of socio-political power of the countries. Furthermore, this scholarship does not problematize the neoliberalism as a system that lies in the root of inequality between different regions and states, including gender inequality amongst their population. When scholars do recognize the gender dynamics of the international division of labour they still do not take into account the class differences between women within same or different regions. The two major categories recognized in this scholarship are poor and exploited women who live and work in the Global South and rich women from the Global North who mainly act through consumerism. Women prisoners in the Global North, working class women who lost or are losing their jobs, women who cannot find a job, women from rural areas as well as women in the semi-peripheries are missing from their analysis. Similarly, women with increased consuming power in the Global South are also omitted. However, not taking the specific conditions of women and men in every context will prove to be a difficulty in analysing the latest developments in global power relations.

The Feminist critique of capitalism and neoliberalism argues that women's labour, in particular women's unpaid labour, has been crucial for the development of exploitative system and accumulation of capital. Hence the debate for waged home labour in the " 70 s of the $20^{\text {th }}$ century initiated by the Italian movement at the time and feminists such as Mariarosa Dalla Costa and Silvia Federici (Barbagallo, 2019). This is the cornerstone of the social reproduction theory, which critiques Marx's failure to acknowledge women's reproductive labour as productive labour. According to the theory of social reproduction, the reproductive labour necessary for creation and maintenance of the labour force is the fundamental element for the development of a system of work relations.

Taking all this in consideration, we argue the research done so far on global development relations is outdated, non-holistic and lacking a gender perspective. In this sense, it is difficult to foresee future solutions in the global relations on a world scale that will not sacrifice women and socially vulnerable categories of people. Hence the need for a symbiosis of the research carried out in global development studies and the research in neo-Marxist feminist critique of neoliberalism. This type of interdisciplinary and intersectional approach towards studies and research will be able to answer the econometric problems on a global scale while taking into account the gendered effects of the socio-economic politics of global development.

Besides, it is crucial to place central the voice of women and men who are directly affected by the new development in labour relations on a global 
scale. Whilst economy and economic progress are immensely important for states, without respecting the principle of social upgrade and wellbeing of the whole population we cannot discuss about economy at all. In that sense, implementing a participatory approach to all stages of policy making from a gender perspective (gender mainstreaming) is a key tool towards achieving gender sensitive policies on a global level that will not victimize nor privilege women from different classes around the world. 


\section{References}

Alonso, A. J. (1983). "The Domestic Clothing Workers in the Mexican Metropolis and Their Relation to Dependent Capitalism" in Nash, J. and Fernández-Kelly, M. ed. Women and Men and the International Division of Labour. Albany: State University of New York Press, pp 161 172.

Armbruster - Sandoval, R. (2005). Globalization and Cross Border Labour Solidarity in the Americas: The Anti-Sweatshop Movement and the Struggle for Global Justice. New York: Routledge.

Barbagallo, C. (2019). "Introduction: Women and the Subversion of the Community: A Mariarosa Dalla Costa Reader" in Plan C. Available at: https://www.weareplanc.org/blog/introduction-women-and-the-subversionof-the-community-a-mariarosa-dalla-costa-reader/ [24 May 2019].

Barrientos, S., Gereffi G., and Rossi, A. (2011). "Economic and social upgrading in global production networks: A new paradigm for a changing world", in International Labour Review 150 (3-4), pp. 319 - 240.

Bernhardt, T. and Milberg, W. (2011). "Economic and Social Upgrading in Global Value Chains: Analysis of Horticulture, Apparel, Tourism and Mobile Telephones". Capturing the gains. New York: School for Social Research.

Bernhardt, T. and Pollack, R. (2015). "Economic and social upgrading dynamics in global manufacturing value chains: A comparative analysis", in Environment and Planning A 0(0), pp. 1 - 25.

Benería, L. (1989). "Gender and the Global Economy", in Anuari de la Societat Catalanad'Economia 8, pp. $79-88$.

Bhattacharya, T. (2014).“Explaining Gender Violence in the Neoliberal Era”, in International Socialist Review. Available at: https://isreview.org/issue/91/explainin-gender-violence-neoliberal-era [30 November 2018].

Davis, A. (2003). Are Prisons Obsolete? New York: Seven Stories Press.

DuVernay, A. (2016). 13 th . Documentary. USA: Kandoo Films, Forward Movement.

Enloe, C. (1983). "Women Textile Workers in the Militarization of Southeast Asia" in Nash, J. and Fernández-Kelly, M. ed. Women and Men and the International Division of Labour. Albany: State University of New York Press, pp. 407 - 426.

Federici, S. (2004). Caliban and the Witch. New York: Automedia.

Foucault, M. (1975). Discipline and Punish: The Birth of the Prison. New York: Vintage Books. 
Fraser, N. (2016). "Contradictions of Capital and Care", in New Left Review 100 , pp. $88-117$.

Fröbel, F., Heinrichs J. and O. Krëye (1978). “The New International Division of Labour", in Social Science Information SAGE Journals, 17 (1), pp. 123142.

Gamburd, M. R. (1998). "Class Identity and the International Division of Labor: Sri Lanka's Migrant Housemaids", in Anthropology Faculty Publications and Presentations.Portland: Portland State University.

Ѓуровска, М. (2008). Соцчиологија на женскиот труд. Скопје: Универзитет „Св. Кирил и Методиј”.

Komlosy, A. (2018). Work: The Last 1000 Years. London, New York: Verso.

Lim, L. (1983). "Capitalism, Imperialism, and Patriarchy: The Dilemma of Third-World Women Workers in Multinational Factories" in Nash, J. and Fernández-Kelly M. ed. Women and Men and the International Division of Labour. Albany: State University of New York Press, pp. 70 - 93.

Mies, M. (2014). Patriarchy and Accumulation on a World Scale: Women in the International Division of Labour. $3^{\text {rded. }}$ with a Foreword by Silvia Federici. London: Zed Books Ltd.

Milberg, W. and Winkler D. (2013).Outsourcing Economies: Global Value Chains in Capitalist Development. Cambridge: Cambridge University Press.

Nash, J. (1983). “The Impact of the Changing International Division of Labor on Different Sectors of the Labor Force" in Nash, J. and FernándezKelly M. ed. Women and Men and the International Division of Labour. Albany: State University of New York Press, pp. 3 - 39.

Ong, A. (1983). "Global Industries and Malay Peasants in Peninsular Malaysia" in Nash, J. and Fernández-Kelly M. ed. Women and Men and the International Division of Labour. Albany: State University of New York Press, pp. 426 - 440.

Petkovska, N. (2016). “Textile Factories City: Gender Violence and Housewifization in the Small City of Shtip in the Republic of Macedonia", in Lefteast. Available at: http://www.criticatac.ro/lefteast/textile-factoriescity/. [30 November 2018].

Power, N. (2009). One-Dimensional Woman. UK: O Books, John Hunt Publishing Ltd.

Snow, R. (1983). "The New International Division of Labor and the U.S. Work Force: The Case of the Electronics Industry", in Nash, J. and Fernández-Kelly M. ed. Women and Men and the International Division of Labour. Albany: State University of New York Press, pp. 39 - 70.

Squires, N. (2013) "Jailhouse Hock: Italian inmates produce prison wine" in The Telegraph. Available at: https:/www.telegraph.co.uk/news/world- 
news/europe/italy/10091575/Jailhouse-Hock-Italian-inmates-produceprison-wine.html[ on 10 April, 2019]

Staritz, C., Morris, M. and Plank, L. (2016). “Clothing Global Value Chains and Sub-Saharan Africa: Global Exports, Regional Dynamics and Industrial Development Outcomes" in International Trade Working Paper 16, pp. $3-23$.

Vogel, L. (2013). Marxism and the oppression of women: Toward a Unitary Theo$r y .2^{\text {nd }}$ ed. Chicago: Haymarket Books. 